\title{
Students Perception' toward The Role of YouTube Video in Improving Their Speaking Skills
}

\section{Persepsi Siswa terhadap Peran Video YouTube dalam Meningkatkan Keterampilan Berbicara Mereka}

\author{
Saraswati, Rahmati Putri Yaniafari*, Niamika El Khoiri \\ Universitas Negeri Malang, Jl. Semarang No. 5 Malang, Jawa Timur, Indonesia \\ *Penulis korespondensi, Surel: yaniafari.fs@um.ac.id
}

Paper received: 02-10-2021; revised: 23-11-2021; accepted: 29-12-2021

\begin{abstract}
YouTube video is one of the media for improving students' speaking skills. This survey study aimed to explore students' perception toward the role of YouTube video in speaking skill improvement. The subject of the research is 188 students of the English department in Universitas Negeri Malang. An online questionnaire was distributed to collect data to the 2017, 2018, 2019 cohorts of English Language Teaching (ELT) in Universitas Negeri Malang. Items in the questionnaire were adapted from some questionnaires developed by Alkathiri (2019). The result demonstrated that YouTube video was an effective medium to enhance students speaking skill improvement and can be applied as an alternative media for the self-direct speaking learning process. Furthermore, students feel helped by the existence of YouTube to improve their speaking skills, such as increasing the number of new vocabularies, improving pronunciation, and helping them speak fluently. It can be concluded that the use of YouTube is able to improve students speaking skills.
\end{abstract}

Keywords: YouTube, language learning, speaking skill improvement.

\begin{abstract}
Abstrak
Video YouTube adalah salah satu media untuk meningkatkan keterampilan berbicara siswa. Studi survei ini bertujuan untuk mengeksplorasi persepsi siswa terhadap peran video YouTube dalam peningkatan keterampilan berbicara. Subjek penelitian ini adalah mahasiswa Jurusan Bahasa Inggris di Universitas Negeri Malang. Kuesioner dibagikan secara online untuk mengumpulkan data dari mahasiswa angkatan 2017, 2018, 2019 Prodi Pendidikan Bahasa Inggris di Universitas Negeri Malang. Item dalam kuesioner diadaptasi dari beberapa kuesioner yang dikembangkan oleh Alkathiri (2019). Hasil penelitian menunjukkan bahwa video YouTube merupakan media yang efektif untuk meningkatkan peningkatan keterampilan berbicara siswa dan dapat diterapkan sebagai media alternatif untuk proses pembelajaran berbicara mandiri. Lebih lanjut, siswa merasa terbantu dengan adanya YouTube untuk meningkatkan keterampilan berbicara mereka, seperti menambah jumlah kosakata baru, meningkatkan pengucapan, dan membantu mereka berbicara dengan lancar. Dapat disimpulkan bahwa penggunaan YouTube mampu meningkatkan keterampilan berbicara siswa. dalam belajar dan berlatih menulis teks naratif. Selain itu, komik dipandang berhasil meningkatkan kualitas teks naratif yang ditulis oleh siswa.
\end{abstract}

Kata kunci: YouTube, pembelajaran bahasa, peningkatan keterampilan berbicara.

\section{Introduction}

Speaking is a crucial point in language teaching. In the context of developing the role of English in Indonesia, speaking capacity appears to be the primary target for English learners both at the school, university, and general learner. Until now, the English language continues to be used by international community for the aspect of the language of business, tourism, science, entertainment, computer technology, and media on the worldwide level. English has attained the status of the global language and is spoken all over the world. According to Faisal (2019), 
English is the language extensively used within the area of business, banking, technology and information, the internet, education, entertainment, engineering, media and newspapers, medicine, scientific research, travel, and tourism, software. Therefore, students should increase their English, especially speaking skills.

According to Aleksandrzak (2011), the problem that is commonly faced by students in the process of learning speaking is inhibition, fear of making mistakes, mother tongue use, nothing to say. The students want to speak English, but sometimes they feel difficult to do that. Therefore, those problems that is commonly faced by the students must be observed to achieve success in learning to speak.

To make the learning process succeed, students need an effective medium or tool to help them achieve it. One of the media that the students can use for learning speaking is YouTube. The use of this media provides several advantages, including that it can be accessed anytime and anywhere-one of the supporting media for internet-based learning that can visualize good learning techniques and materials. Through YouTube, students can load, watch and share video clips for free. According to Riswandi (2016), to support that, YouTube is an alternative medium to enhance students' speaking skills. Therefore, YouTube in the learning process will intensify students' understanding and mastery of language.

According to Long (1989), since the 1970s, the field of adult education and adult educators have become increasingly interested in independent learning. Adult learners such as EFL students need the freedom to direct their focus alone. Barriers in adult learners like EFL students include problems with time, money, self-confidence, or curiosity, lack of information about learning opportunities, scheduling problems, and others. Thus, EFL students need to selfdirect learning outside the classroom. According to Knowles (1980), Self-learning is learning in which learners have their own learning process approach that has power over all mechanical aspects.

Adults are autonomous and self-directed in being responsible for their own learning and enriching their education. They have a great deal of accumulated experience in their learning process. According to Helen W. Post (n.d.), adults need a practical approach to learning, and they want hands-on experience in things they can use now. One of the facilities available on the internet and commonly used by students is YouTube. YouTube is part of the advancement of information technology (IT) in today's era of globalization. YouTube is a website that shares various kinds of videos like video clips, short original videos, music videos, TV clips, movie trailers, and other content, namely video blogging and educational videos. It offers the students online materials in the learning process (Almurashi, 2016). It additionally gives amusing and fast access to instruction, cultural-primarily based totally videos, and language from everywhere in the all over the world (Terantino, 2011). Using YouTube both outside or within the classroom can enhance pronunciation, conversations ability and enhance authentic vocabulary development (Watkins \& Wilkins, 2011). Further, using YouTube will help EFL students learn independently and take responsibility for their own learning. Therefore, YouTube is the most appropriate media for learning speaking.

Kurniawan (2018) found in his research that every student has a YouTube account, and every day, they usually use it for many things and reasons, such as watching the hot issue, listening to music, watching films, and many more. To improve students' speaking skills, it is suitable for a teacher to utilize YouTube to learn speaking. The gap of the current research is 
the instrument in collecting data. This research using questionnaire and interview for collecting the data. In contrast, this research just using a questionnaire. Alkathiri (2019) additionally discovered in his research that the usage of YouTube minimize student's anxiety in the class, offer learners the delight of choosing the videos, encourage them to ask answer questions, make them sense comfortable, permit the learners to apply the appropriate grammar and vocabulary, and deliver student motivation to learn. He additionally discovered that YouTube videos allow students to arrange their concept while speaking, assist them increase the vocabulary that they learn, help them guess the unusual words that they do not know the meaning of, and assist them talk fluently. The students also felt the materials on YouTube have been authentic. Therefore, students were capable of apprehend how to speak English based totally at the real-international context. The gap of the current research is the variable. The previous research just focused on attitude toward using YouTube in improving students' motivation to speak. While this research focusing on the role of YouTube in improving student speaking skill.

Based on the studies above, this research aims to investigate students' perceptions toward the impact of YouTube videos on student speaking skills. The study's objective is to describe the student perception toward the role of YouTube video in speaking skills improvement.

\section{Methods}

This study used a survey a research design. The subject of this study is 188 an English language teaching (ELT) student in Universitas Negeri Malang in academic years 2017-20182019. The reasons why the researcher chooses these subjects. First, because most of them already know how to access video on the YouTube application and 100\% of the students are internet citizens, it can help the researcher explore their experience of utilizing YouTube to speaking skill improvement, making them potential respondents for this study. Secondly, they have passed all the basic skills or intensive course, and they need media that can be more incredible their skills in the field of English, especially in speaking subject, and by obtaining data from students who have passed the intensive course, the researcher expected that the result of the study more reliable. Third, they have studied in the English department for the third semester, which makes them highly motivated to increase their speaking skill in their way of learning English.

The researcher's instrument is a questionnaire using Google Forms to obtain the data from respondents. To collect the data from student online questionnaire was used. The questionnaire was adapted from research of Alkathiri (2019), about "Students' Perspectives towards Using YouTube in Improving EFL Learners' Motivation to Speak." The researcher adopted the questionnaire because the researcher wants to adjust to this research and only makes the questionnaire in Alkathiri's journal as a reference. The questionnaire aimed to explore student perception toward the role of YouTube video in speaking ability consist of 14 items. There are two parts presented in the questionnaire. In the first part, six statements were about YouTube use in language learning. The second part eight statements were about the role of YouTube in speaking skill improvement. There are four scale options in the form of the questions: strongly agree, agree, disagree, and strongly disagree. The researcher has some procedures applied in collecting the data. The researcher arranged the questions in the form of multiple-choice to make respondents easy to choose and answer the questions. After the questionnaire is constructed, make sure that the questionnaire is clear enough and receive a 
positive response from the respondents. Then, the researcher will distribute an online questionnaire to respondents with brief explanations of the purpose of the study. After the student fills out and submits the questionnaire, then the researcher will analyze it.

Researcher analyzed the data by following some steps. First, the researcher collected the data from questionnaire, then data that researcher get from the questionnaire were analyzed by using Google Forms in the form of percentage. After that, Data analysis that was collected in google form will elaborate into paragraphs. The students' response obtainable from the Likert scale was classified into two options: negative and positive responses. It is become a positive categorize if the students agree with the statement in the questionnaire. Meanwhile, it is become a negative categorize if the student disagrees with the statement in the questionnaire. The perception of the item will assess 4-3-2-1 and rated on a scale of 3-2-1. Scale 3 indicated a positive perception of the item description, which covered value 4 (strongly agree). Scale 2 indicated that they had a negative perception about the item (Disagree), and scale 1 indicated that they had a negative perception of the item description, which covered value 1 (strongly disagree).

\section{Finding and Discussion}

This part presents the results of the study. It indicates the results of studies pattern responses to questionnaire items. The outcome of the field study is interpreted, Base on the research question. After offering the results in the table, the findings are discussed and related to the literature and previous research that addresses the studies topic.

\subsection{YouTube in language learning}

Table 1. Learners' Perception Concerning YouTube in Language Learning

\begin{tabular}{|c|c|c|c|c|c|}
\hline \multirow{3}{*}{ Items } & \multirow{3}{*}{ Statement } & 1 & 2 & 3 & 4 \\
\hline & & $\begin{array}{l}\text { Strongly } \\
\text { disagree }\end{array}$ & Disagree & Agree & $\begin{array}{c}\text { Strongly } \\
\text { agree }\end{array}$ \\
\hline & & \multicolumn{4}{|c|}{ frequency/percentage } \\
\hline \multirow[t]{2}{*}{1} & YouTube is a beneficial tool for language & 0 & 0 & 48 & 140 \\
\hline & learning & $0.0 \%$ & $0.0 \%$ & $25.5 \%$ & $74.5 \%$ \\
\hline \multirow[t]{2}{*}{2} & You learn English faster and better by & 0 & 6 & 96 & 89 \\
\hline & using YouTube & $0.0 \%$ & $3.0 \%$ & $51.3 \%$ & $45.7 \%$ \\
\hline \multirow[t]{2}{*}{3} & YouTube learning activities are very & 0 & 5 & 74 & 109 \\
\hline & interesting and motivating & $0.0 \%$ & $2.5 \%$ & $39.5 \%$ & $58 \%$ \\
\hline \multirow[t]{2}{*}{4} & YouTube videos allow you to use the & 1 & 17 & 86 & 84 \\
\hline & $\begin{array}{l}\text { appropriate vocabulary and correct } \\
\text { grammatical forms }\end{array}$ & $0.5 \%$ & $8.5 \%$ & $46.3 \%$ & $44.7 \%$ \\
\hline \multirow[t]{2}{*}{5} & You feel more comfortable in using & 0 & 7 & 82 & 99 \\
\hline & YouTube to learn English & $0.0 \%$ & $3.5 \%$ & $43.8 \%$ & $52.7 \%$ \\
\hline \multirow[t]{2}{*}{6} & You enjoy choosing materials on & 0 & 8 & 68 & 112 \\
\hline & YouTube in learning English & $0.0 \%$ & $4.0 \%$ & $36.4 \%$ & $59.6 \%$ \\
\hline
\end{tabular}

In the first statement, YouTube is a beneficial tool for language learning. $74.5 \%$ of students are strongly agreed with the statement; $25.5 \%$ of students agreed. Meanwhile, $0 \%$ of students disagree and strongly disagreed with the statement. It means the students perceived positive in using YouTube in English language learning. The above findings are supported by Alimemaj (2010) who suggested that YouTube videos have many benefits within the area of language learning. The identical result was shown by Meinawati, Harmoko, Rahmah, and Dewi (2020). YouTube is a powerful device which can enhance the learning experience if the 
video is certainly applicable to the subject at hand. Additionally, Riswandi (2016) along with Shariff and Shah (2019) supported these findings associated with students; review in using the application YouTube; they considered it a device that assist them manage, control, and have freedom of their desire in improving their studying outcome.

The second statement aims to know whether students learn better by using YouTube videos. The number of students who chose strongly agree is $45.7 \%$. More than half of students (51.3\%) agreed by using the application YouTube students learn faster and better. However, there are $3 \%$ disagreed, and no one student strongly disagreed with this statement. It is because watching interesting videos and hearing how the speaker pronounces it will make students more motivated to practice it so that it will affect students' comprehension in learning speaking. Also, this finding corresponds with Almurashi (2016), YouTube videos combine spoken language with visual context and develop learners' ability to understand and enjoy the English lessons.

The third statement is intended to know whether learning activities on YouTube are interesting for students. The percentages of the students who strongly agreed were $58 \%$, and $39.5 \%$ of students agreed with this statement. Meanwhile, only $2.5 \%$ disagreed, and nobody stated strongly disagreed. YouTube provides various interesting videos so that students can easily choose which speaking learning videos are suitable for them, both visuals in videos or teaching methods, American or British accents, high or medium vocabulary, and many more. This finding is supported by Alimemaj (2010) and Lee (2014) mentioning that English language teachers are interested using YouTube in their learning process since it indicates to them a new manner which they suppose goes to increase their students' English language knowledge and assist them within the academic setting.

The fourth statement talks about YouTube videos allow you to apply the proper vocabulary and accurate grammatical forms. The questionnaire presents that $44.7 \%$ of the students strongly agreed, more than half of students $(46.3 \%)$ agreed with the statement. The percentage of students who disagreed is $8.5 \%$, and $0.5 \%$ of students strongly disagreed. it shows that the students agreed that YouTube videos permit them to usage the right vocabulary and accurate grammatical forms. Riswandi (2016) supported these finding reported that watching videos on YouTube also unconsciously help the students automatically learning grammar and the nature of the video, which presents audio and picture on the equal time, is able to assist the students enrich their vocabulary, train their pronunciation, and lead them easier to find an idea in producing sentences while speaking.

The following statement of this part aims to know whether YouTube makes students feel more comfortable in learning English. 52.7\% of students strongly agreed, and 43.8\% agreed with this statement. Then, only $3.5 \%$ of students agreed, and nobody strongly disagreed with this statement. This indicates that students indeed feel more comfortable learning English by using YouTube. YouTube can be accessed anytime and anywhere. If students are bored with the class atmosphere, they can learn with YouTube outside the classroom, such as at home, in the park, or anywhere they feel comfortable and quickly remember and capture lessons. This finding corresponds with Balcikanli (2010), who said that learning English does not only includes classroom experience. It happened too outside the classroom where the learning takes place independently. This independent learning outside the classroom offers a wide 
variety of possible online material for the learner to study and increase their ability in speaking.

The sixth statement is about students who enjoy for choosing materials on YouTube in learning English. More than half of students (59.6\%) strongly agreed, $36.4 \%$ of students stated agreed with the statement. $4 \%$ of students stated disagreed, and no one strongly disagreed. It shows that students choosing the materials on YouTube just need to type in the keyword "learn English," and then the site will offer many options, including Learn English with AJ Hook, Learn English Funny, Learn English with Songs, and many more. Thus, students are very spoiled with various conveniences and can choose topics according to their needs. Students feel easy to find the learning materials on YouTube and comfortable use it in teaching English (Binmahboob, 2020). The identical result is discovered by Silviyanti (2014) who mentioned that YouTube videos are a good source for learning speaking

\subsection{YouTube in Speaking Skill Development}

Table 2. Learners' Perception Concerning YouTube in their Speaking Skill Development

\begin{tabular}{clcccc}
\hline \multirow{2}{*}{ Stems } & & 1 & 2 & 3 & 4 \\
& & \multicolumn{1}{c}{$\begin{array}{c}\text { Strongly } \\
\text { disagree }\end{array}$} & Disagree & Agree & $\begin{array}{c}\text { Strongly } \\
\text { agree }\end{array}$ \\
\cline { 3 - 6 } & & \multicolumn{3}{c}{ frequency/percentage } \\
\cline { 3 - 6 } 7 & YouTube videos allow you to organize & 0 & 14 & 90 & 84 \\
& while speaking & $0.0 \%$ & $7.0 \%$ & $48.3 \%$ & $44.7 \%$ \\
\hline \multirow{2}{*}{8} & YouTube videos increase the number of & 0 & 12 & 61 & 115 \\
& new words you learn & $0.0 \%$ & $6.0 \%$ & $32.4 \%$ & $61.6 \%$ \\
\hline \multirow{2}{*}{9} & Your pronunciation improved when you & 0 & 9 & 75 & 104 \\
& learn via YouTube & $0.0 \%$ & $4.5 \%$ & $40.2 \%$ & $55.3 \%$ \\
\hline \multirow{2}{*}{10} & YouTube videos help you guess the & 1 & 16 & 84 & 87 \\
& meaning of unfamiliar words & $0.5 \%$ & $8.0 \%$ & $45.2 \%$ & $46.3 \%$ \\
\hline \multirow{2}{*}{11} & YouTube videos help you speak fluently & 0 & 16 & 100 & 72 \\
& & $0.0 \%$ & $8.0 \%$ & $53.2 \%$ & $38.8 \%$ \\
\hline \multirow{2}{*}{12} & YouTube videos help you segment the & 1 & 13 & 115 & 59 \\
& Stream of speech into recognizable units & $0.5 \%$ & $6.5 \%$ & $61.6 \%$ & $31.4 \%$ \\
\hline 13 & YouTube videos prevent you form going & 0 & 13 & 114 & 61 \\
& astry while speaking & $0.0 \%$ & $6.5 \%$ & $60.6 \%$ & $32.9 \%$ \\
\hline 14 & You better understand the material ehen & 1 & 9 & 84 & 94 \\
& you watch a YouTube video about it & $0.5 \%$ & $4.5 \%$ & $45.2 \%$ & $50.3 \%$ \\
\hline
\end{tabular}

Table 2 indicates the responses of the students to the usage of YouTube in their speaking skill development. According to data presentation, it could be seen in statement 7, 44.3\% and $44.7 \%$ of students agreed and strongly agreed with the statement. Then only $7 \%$ of students disagreed, and nobody stated strongly disagree. It is because by watching videos on YouTube, students will get a little idea ofwhat they are going to talk about so they can organize their ideas. Syafiq, Rahmawati, Anwari, and Oktaviana (2021) supported this study, reporting that YouTube videos presents audio and images; thus can help students easier to find ideas in generating sentences while speaking, practice pronunciation, and enrich their vocabulary.

In statement 8, using YouTube videos in learning can increase the students' vocabulary. The table present that $61.6 \%$ of participant stated strongly agree, $32.4 \%$ expressed agree. Meanwhile, $6 \%$ of participants stated they disagree, and no one strongly disagrees. It is shown that students feel helped by the existence of YouTube so that they can improve their speaking skills. The videos on YouTube also contain many various things such 
as education, culture, economy, business, lifestyle, etc. Watching students will also vary; this makes students often listen to remember new vocabulary. Kabooha and Elyas (2018) supported this research finding by stating that most of the students found YouTube to help improve their understanding of the English vocabulary. The same result was confirmed by Terantino (2011). YouTube additionally offers the way for students to get information and education from all around the world, thus providing them an opportunity to interact meaningfully in the target language.

In statement 9 this part is to know whether the students' pronunciation improves when they are learning via YouTube videos. More than half of students (55.3\%) strongly agreed with the statement, $40.2 \%$ of students are agreed that their pronunciation improved when they learned via YouTube video. However, $4.5 \%$ of the students stated they disagreed, and nobody strongly disagreed. It means that students feel their pronunciation improves when they learn via YouTube videos. Sitoresmi (2016) also stated that YouTube provides tongue twister videos that give exposure of native speaker pronunciation required by students so that students have the opportunity to listen to native speakers and to see how they transfer tongue and mouth when using tongue twisters from videos. Therefore, YouTube can increase students' pronunciation, so that they can speak fluently. The same result by Silviyanti (2014) showed that almost all of the teachers also believed that the usage of YouTube videos can solve students' pronunciation and intonation troubles through listening and see the content material of those videos that may incorporate native English speakers who probably will convey a accurate form of clearly pronounced words.

The following statement is intended to know whether YouTube videos assist students to guess the meaning of unfamiliar words. The questionnaire presents $46.3 \%$ strongly agreed, $45.2 \%$ agreed with this statement. However, $8 \%$ stated disagree, and $0.5 \%$ strongly disagreed with the statement. When watching a short video on YouTube by looking at the body language of the person in the video or the storyline on the video, students will be able to guess words that are not familiar to them. The same result was confirmed by Binmahboob (2020) who reported students responses denoted that YouTube enables students to improve their speaking skills, guides students, and YouTube videos can assist students guess the meaning of unfamiliar words.

In statement 11 is about YouTube videos help students to speak fluently. $38.8 \%$ of the students strongly agreed, more than half of students (53.2\%) expressed agree. Meanwhile, only 8\% expressed disagreement that YouTube videos help students speak fluently, and $0 \%$ strongly disagreed. It is because, on YouTube, there are many ways to speak fluently; if students watch the video and then practice it, it will make them fluent in speaking English. This finding is supported by Meinawati et al. (2020), who reported watching YouTube videos helped students speak more fluently and confidently. Additionally, Silviyanti (2014) along with Watkins and Wilkins (2011) said that YouTube is one of the precious strategies that may be used to expand students' speaking skills.

Statement 12 on the table is about YouTube videos can assist students to segment the stream of speech into recognizable units. $31.4 \%$ of students expressed strongly agree, more than half of students (61.6\%) stated agree that YouTube videos assist them segment their speech into recognizable units. Then, only $6.5 \%$ of students stated disagree, and no one strongly disagreed. This is because many videos contain a lot of informal learning from easy to 
difficult from low to high vocabulary so that students can easily understand speech that is difficult for them. Khalid and Muhammad (2012) supported these findings by stating that YouTube is more effective than textbook-based courses in overcoming learners' difficulties.

In statement 13 is aimed to know whether YouTube videos avoid the students from going astray while speaking. $32.9 \%$ of students strongly agreed with this statement, $60.6 \%$ of the students stated agreed. While only $6.5 \%$ of the students stated disagree that YouTube videos prevent them from going astray while speaking, and no one strongly disagrees with the statement. Because videos on YouTube provide visual context with spoken language and images, students can understand and enjoy learning. Therefore, students feel YouTube videos maintain them from going deviate while speaking. Deng and Yuen (2011) supported this finding by arguing that YouTube is an internet-primarily based totally instructional device that motivate students to study due to the videos and graphics it offers to the learners

The last statement is about the students will understand the material better when they watch a YouTube video. The table presents, more than half of the students (50.3\%) strongly agreed with the statement, $44.7 \%$ of students agreed. Meanwhile, $4.5 \%$ of the students disagreed, and $0.5 \%$ of students stated strongly disagreed with the statement. It is because the videos on YouTube, in addition to providing explanations, also provide many examples such as how to pronounce well, practice conversation; even when they learn by watching the video, they can clearly see the position of the mouth when native speakers speak. Ghasemi, Hashemi, and Bardine (2011) who reported that the real advantage of YouTube from a language learning point of view is that it offers authentic examples of everyday English used by everyday people.

In addition, YouTube is a good medium for learning speaking, in term of interesting, motivating, comfortable, enjoyable and easy to access. YouTube also an influential medium for developing students in learning speaking in term of vocabulary, grammar, pronunciation and fluently. Furthermore, students get many positive impacts in using YouTube for improving their speaking skill and they give positive perception toward the role of YouTube in speaking ability development.

\section{Conclusions and Suggestions}

Students' perceptions of YouTube's role in speaking skill improvement are mostly positive. Most of the students agreed that YouTube helps their speaking much better. They agreed that learning English by using YouTube increases their vocabulary and enlarges pronunciation ability, it can be seen in the result of the questionnaire. Further, YouTube was a valuable tool for student speaking skill improvement. The weaknesses of this study, only knowing students' perceptions through a questionnaire did not do more in-depth research using interviews with respondents. It is hoped that further researcher can improve this research by collecting the data through questionnaire and interview. Besides that, this study can be used as a reference for future researcher. Also, it will give inspirations or additional meaningful information in conducting the following research related to the media in teaching speaking. This research is expected to be useful for English teacher to select the appropriate media for students in learning speaking. 


\section{Reference}

Aleksandrzak, M. (2011). Problems and challenges in teaching and learning speaking at advanced level. Glottodidactica: An International Journal of Applied Linguistics 37, 37-48. doi: https://doi.org/10.14746/gl.2011.37.3

Alimemaj, Z. (2010). YouTube, language learning and teching techniques. The Magazine of Global English Higher Education, 2(3), 10-12.

Alkathiri, L. A. (2019). Students' perspectives towards using YouTube in improving EFL Learners' motivation to speak. Journal of Education and Culture Studies, 3(1), 12-30. doi: https://doi.org/10.22158/jecs.v3n1p12

Almurashi, W. A. (2016). The effective use of YouTube videos for teaching English language in classrooms as supplementary material at Taibah University in Alula. International Journal of English Language and Linguistics Research, 4(3), 32-47. Retrieved from https://www.eajournals.org/wp-content/uploads/TheEffective-Use-of-YouTube-Videos-for-Teaching-English-Language-in-Classrooms-as-SupplementaryMaterial-at-Taibah-University-in-Alula.pdf

Balcikanli, C. (2010). Long live, YouTube: L2 stories about YouTube in language learning. Annals of Language and Learning: Proceedings of the 2009 International Online Language Conference (IOLC 2009), 91-96.

Binmahboob, T. (2020). YouTube as a learning tool to improve students' speaking skills as perceived by EFL teachers in Secondary School. International Journal of Applied Linguistics \& English Literature, 9(6), 1322. doi: http://dx.doi.org/10.7575/aiac.ijalel.v.9n.6p.13

Deng, L., \& Yuen, A. H. K. (2011). Towards a framework for educational affordances of blogs. Computers \& Education, 56(2), 441-451. doi: https://doi.org/10.1016/j.compedu.2010.09.005

Faisal, K. (2019). The importance of speaking skills in English classrooms. Alford Council of International English \& Literature Journal(ACIELJ), 2(2), 1-12. Retrieved from https://www.acielj.com/v2i2.html

Ghasemi, B., Hashemi, M., \& Bardine, S. H. (2011). UTube and language learning. Procedia - Social and Behavioral Sciences, 28, 63-67. doi: https://doi.org/10.1016/j.sbspro.2011.11.013

Post, H. W.. (n.d.). Teaching adults: What every trainer needs to know about adult learning styles. Utah: Utah Parent Center. Retrieved from https://www.ioaging.org/wp-content/uploads/2015/03/teachingadultswhattrainersneedtoknow-sml.pdf

Kabooha, R., \& Elyas, T. (2018). The effects of YouTube in multimedia instruction for vocabulary learning: Perceptions of EFL students and teachers. English Language Teaching, 11(2), 72-81. doi: https://doi.org/10.5539/elt.v11n2p72

Khalid, A., \& Muhammad, K. (2012). The use of YouTube in teaching English literature: The case of Al-Majma'ah Community College, Al-Majma'ah University (case study). International Journal of Linguistics, 4(4), 525551. doi: https://doi.org/10.5296/ijl.v4i4.2930

Knowles, M. S. (1980). The modern practice of adult education: From pedagogy to andragogy (revised and updated). Englewood Cliffs, NJ: Cambridge Adult Education.

Kurniawan, I. (2018). Student's perception on the use of YouTube as a learning media to improve their speaking skill. Proceedings of the International Seminar and Annual Meeting BKS-PTN Wilayah Barat, 1(1), 324-329. Retrieved from http://conference.unsri.ac.id/index.php/semirata/article/view/1130

Lee, S.-H. (2014). Digital literacy education for the development of digital literacy. International Journal of Digital Literacy and Digital Competence, 5(3), 29-43. doi: https://doi.org/10.4018/ijdldc.2014070103

Long, H. B. (1989). Self-dircted learning: Emerging theory \& practice. Oklahoma: Oklahoma Research Center for Continuing Professional and Higher Education, University of Oklahoma.

Meinawati, E., Harmoko, D. D., Rahmah, N. A., \& Dewi, N. (2020). Increasing English speaking skills using YouTube. Polyglot: Jurnal Ilmiah, 16(1), 1-13. doi: http://dx.doi.org/10.19166/pji.v16i1.1954 
Riswandi, D. (2016). Use of YouTube-based videos to improve students' speaking skill. Proceeding of the International Conference on Teacher Training and Education, 2(1), 298-306. Retrieved from https://jurnal.uns.ac.id/ictte/article/view/8150

Shariff, S. B. M., \& Shah, P. M. (2019). Pupils perception of using YouTube and autonomous learning. Creative Education, 10(13), 3509-3520. doi: https://doi.org/10.4236/ce.2019.1013270

Silviyanti, T. M. (2014). Looking into EFL students' perceptions in listening by using English movie videos on YouTube. Studies in English Language and Education, 1(1), 42-58. doi: https://doi.org/10.24815/siele.v1i1.1119

Sitoresmi, U. (2016). Tongue twisters in pronunciation class. Proceedings of International Conference on Teacher Training and Education, 1(1) 589-592. Retrieved from https://jurnal.fkip.uns.ac.id/index.php/ictte/article/view/7673

Syafiq, A. N., Rahmawati, A., Anwari, A., \& Oktaviana, T. (2021). Increasing speaking skill through YouTube video as English learning material during online learning in pandemic Covid-19. Elsya: Journal of English Language Studies, 3(1), 50-55. doi: https://doi.org/10.31849/elsya.v3i1.6206

Terantino, J. M. (2011). YouTube for foreign languages: You have to see this video. Language Learning \& Technology (15)1, 10-16. $\quad$ Retrieved from https://digitalcommons.kennesaw.edu/cgi/viewcontent.cgi?article=2616\&context=facpubs

Watkins, J., \& Wilkins, M. (2011). Using YouTube in the EFL classroom. Language Education in Asia, 2(1), 113119. doi: 10.5746/LEiA/11/V2/I1/A09/Watkins_Wilkins 